\title{
Influential Factors for Effective Materials Management in Construction Projects
}

\author{
Zairra Mat Jusoh ${ }^{1}$, Narimah Kasim ${ }^{1 *}$, Magaji Umar Ibrahim ${ }^{2}$, Norliana Sarpin ${ }^{1}$, Hamidun Mohd Noh ${ }^{1}$, \\ Rozlin Zainal ${ }^{1}$
}

\author{
${ }^{1}$ Department of Construction Management, Universiti Tun Hussein Onn Malaysia, 86400 Batu Pahat, Johor, \\ Malaysia \\ ${ }^{2}$ Federal College of Education (Technical) Gombe State, Nigeria \\ *Corresponding e-mail :narimah@uthm.edu.my
}

Received 6 June 2018; Revised 29 November 2018; Accepted 30 December 2018

DOI: https://10.30880/ijscet.2018.09.02.005

\begin{abstract}
Construction projects are plagued with the issue of poor project performance such as low productivity, wastage, time overrun, compromised quality and cost overrun. Research literature reveals that this issue occurs partly due to ineffective materials management. Nonetheless, the effective management of materials seems like a viable solution to enhance the performance of any construction projects. Despite its importance, not much literature has explored the influential factors for effective management of materials. Since the identification of factors is an essential step to recommend any improvement efforts, thus, this paper examines the influential factors for effective materials management. A questionnaire survey was conducted with practitioners from contractor organisations and 111 valid responses were obtained. Data was analysed using exploratory factor analysis via the IBM SPSS version 21 software. Results indicate that only 50 influential factors were relevant in Malaysian construction project and these were categorised into 8 specific components namely: management, purchasing, expediting, transportation, site storage and condition, supplier, contractual and governmental interference. Summarily, findings reported in this paper constitute part of a questionnaire development process for a research project undertaken to develop an effective materials management model for better projects performance. Thus, the outcome of this study may assist practitioners in decision making process by understanding the identified influential factors that contribute to effective materials management.
\end{abstract}

Keywords: Influential Factors, Materials Management, Construction Projects, Exploratory Factor Analysis

\subsection{Introduction}

Construction materials contribute significantly to project cost. Several authors claim that this contribution may be up to $70 \%$ of the project cost [1-3]. This contribution varies according to the type of contract that is agreed upon in every construction project [4]. Even though materials management is important, this area has received less attention from academician and researchers, as stressed by previous authors [5-8]. More importantly, past studies do not sufficiently address the influential factors that contributes to effective materials management. These studies only mentioned the factors briefly without further investigation: some only highlight few factors only $[1,3,9,10]$. Likewise, there are various and complex factors associated with effective materials management. These factors could originate from suppliers, contractors, logistics provider, government, consultant as well as clients $[3,9,11,12]$. Hence, identifying these factors is an important step needed to recommend any improvement efforts in ensuring appropriate solutions to the problem of ineffective material management in construction projects [13, 14]. By carrying out this study, results obtained may be useful to construction players especially contractors by providing them insights and understanding of the influential factors needed for effective materials management. With this understanding, contractors may be able to focus their effort, resources and incorporates the most crucial factors in the overall firm's policy to mitigate or eliminate some materials management problems that occur in order to improve materials management 
implementation in construction projects. Thus, this paper aims to explore the influential factors for effective materials management using factor analysis.

Materials management is hence defined as the process of controlling the inventory, planning, handling, receiving, distributing, storing, controlling site usage as well as monitoring $[15,16]$. Some authors interpret materials management as a concept that integrates all function of acquiring the construction materials as well as equipment under one management function $[1,17,18]$. Despite the various depiction of the materials management term, it is acknowledged that the ultimate aim of this management is to ensure the availability of construction materials at the most appropriate time, right location, appropriate quantity and that they are obtained at reasonable cost across all stages of construction [3, 19, 20]. As such, it can be concluded that materials management refers to a concept that integrates all function of planning, controlling, receiving, storing, handling, distributing, usage and monitoring all construction materials as well as equipment under one management for the purpose of ensuring their availability on site.

\subsection{Influential Factors of Effective Materials Management}

Materials management can be affected due to several factors. Several authors have highlighted that among the factors contributing to effective materials management are adequate planning, appropriate site management, efficient supervision, efficient handling, proper storage, efficient control of materials, adequate storage space, proper inventory control and good site accessibility [3, 21]. Meanwhile, among the factors affecting materials management effectiveness are unsystematic flow of materials, fluctuation of materials price, extensive multiple handling, improper sorting of materials, improper materials delivery, poor layout for materials handling, unavailability of up-todate inventory status, delay in materials delivery, excessive paperwork, equipment breakdown, shortage of equipment, poor coordination, inefficient communication, delay in procuring materials, errors in ordering, lack of materials storage, poor materials planning and so on $[6,16,22,23]$. Since these factors affect the material management process and are responsible for ineffective materials management, then, it is necessity to mitigate and addressed these factor in enhancing an effective materials management $[1,10,24,25]$. By addressing these, an effective materials management can be achieved. For this reason, the factors in the original form (i.e., negative perspective) need to be rephrased to become positive perspective. For instance, 'unsystematic flow of materials' becomes 'systematic flow of materials.' By doing so, these factors constitute the influential factors that contribute to the effective materials management instead of the factors that adversely affect the materials management effectiveness.

Meanwhile, the basis that have been adopted in deciding whether the factors are associated with materials management or not is according to the relevancy of the factors itself. Firstly, the priority is given to the factors that are retrieved from prior literature in the area of materials management. These factors must relate to the process and function of materials management in order to be selected. After the identified factors are listed, then the factors are retrieved from literature related to poor project performance are reviewed. By comparing those factors, the decision is made to ensure their suitability in representing the influential factors contributing to effective materials management.

Apart from that, during the reviewing process, there was a situation whereby certain factors were neither related and overlap with each other or termed differently but reflect the same meaning. Therefore, to avoid duplication and redundancy among the list of influential factors, some filtering and modifications were made as recommended by the previous author [26]. Summarily, a total of 56 influential factors were identified and categorised into 8 group as shown in Table 1. Regarding the influential factors and their group classification, since prior researchers do not explicitly specify the classification scheme, the author conducted a preliminary study with 10 experienced practitioners for the purpose of ensuring the appropriateness of the identified factors represent the influential factors of effective materials management as well as their group classification. This approach also has been adopted by prior studies [27, 28]. Meanwhile, Appendix A shows the comprehensive list of the influential factors, sources and country investigated. 
Table 1: Summary of Identified Influential Factors and Groups

\begin{tabular}{|c|l|c|}
\hline No. & \multicolumn{1}{|c|}{ Group } & Number of Influential Factor \\
\hline 1 & Management & 15 \\
\hline 2 & Material Procurement & 9 \\
\hline 3 & Logistics & 10 \\
\hline 4 & Supplier and Manufacturer & 5 \\
\hline 5 & Storage & 4 \\
\hline 6 & Site Condition & 4 \\
\hline 7 & Contractual & 5 \\
\hline 8 & Governmental Interference & 4 \\
\hline
\end{tabular}

\subsection{Methodology}

The survey questionnaires were distributed to the practitioners that working in contractor organisations only. It is suggested that the appropriate sample size for this stage is based on the purpose of conducting this stage and the method of data analysis to be employed [29, 30]. In this process especially for self-developed instrument, it is crucial to determine the nature of latent variables underlying an item set [31], that is, appropriately classifying which influential items belong to which component group. It has been acknowledged that the most suitable technique to determine this is by factor analysis [31,32]. Therefore, exploratory factor analysis was used as the principal component analysis technique that computed via IBM SPSS Statistics. In relation to the exploratory factor analysis, prior studies have highlighted the purpose of this analysis which includes; reducing the number of items, examining the structure between variables and evaluating the construct validity of a scale [32-34]. As the above mentioned reasons, the factor analysis was used for analysing the data in this study.

Meanwhile, there are various opinion about the preferable minimum sample size to perform factor analysis. Some authors recommend using a sample size based on the ratio of items involved (either 10 to 1 ratio or 5 to 1 ratio), while some recommend using a preferable sample as much as 50,100 or larger $[32,34,35]$. Regarding the purpose of instrument development, some suggests a sample between 25 to 40 or 30 samples only $[29,36]$. Whereas some asserts that the modest sample size is 150 for the instrument development process [31]. Since this stage involved in instrument development process and factor analysis was used, hence, a total of 150 questionnaires seem adequate and were distributed randomly to targeted respondents. The researcher administered the questionnaire by email, mail, and hand to respondents. In this questionnaire, the scale that have been adopted is a 7-point Likert scale structure in assessing the significant level for each influential factor contributing to effective materials management. A total of 118 responses were received, but only 111 were useable. The analysis began with the screening data for missing data and outliers. After the screening process, 16 responses needed to be dropped as they were classified as outliers. Outliers are recommended to be dropped because they influence the results of the statistical analysis resulting in skewed distributions [33]. Hence, only 95 responses were retained and used for factor analysis.

The details of respondents profile as listed in Table 2. This table indicates there are two aspects of experience which are experience in industry and experience in managing materials. The latter experience is required because it represents the credentials and the ability of respondents in contributing the findings for this study. Respondents' experience in the industry are presented in descending order they include; less than 6 years $(28.4 \%)$, followed by $6-10$ years $(24.2 \%), 11-15$ years $(20 \%)$ and $16-15$ years $(12.7 \%)$. While between $21-25$ years and more than 25 years of experienced fall within the $4 \%$ to $11 \%$ range ( $4.2 \%$ and $10.5 \%$ respectively). Regarding the experience of respondents in managing materials, almost half of them have experiences less than 6 years. Likewise, the remainder of respondents has experience between 6-10 years (24.2\%), 1115 years $(10.5 \%), 16-15$ years $(11.6 \%)$ and more than 25 years $(4.2 \%)$. Apart from the respondents' experience, their current positions are also sought. Respondents were represented as site engineers $(30.5 \%)$, quantity surveyors (29.5\%), project managers (18.9\%), site supervisors (14.8\%), managing directors $(4.2 \%)$ and contract/architect manager $(2.1 \%)$. 
Table 2: Respondents Profile

\begin{tabular}{|l|c|c|}
\hline \multicolumn{1}{|c|}{ Item } & Number & Percent (\%) \\
\hline 1) Years of experience in industry & & \\
Not more than 6 years & 27 & 28.40 \\
Between 6 to10 years & 23 & 24.20 \\
Between 11 to 15 years & 19 & 20.00 \\
Between 16 to 20 years & 12 & 12.70 \\
Between 21 to 25 years & 10 & 4.20 \\
More than 25 years & & 10.50 \\
2) Years of experience in managing material & 47 & 49.50 \\
Not more than 6 years & 23 & 24.20 \\
Between 6 to10 years & 10 & 10.50 \\
Between 11 to 15 years & 11 & 11.60 \\
Between 16 to 20 years & 0 & 0.00 \\
Between 21 to 25 years & 4 & 4.20 \\
More than 25 years & & \\
Current position in the firm Managing & 4 & 4.20 \\
director & 2 & 2.10 \\
Contract/Architect manager & 18 & 18.90 \\
Project manager & 29 & 30.50 \\
Site engineer & 28 & 29.50 \\
Quantity surveyor & 14 & 14.80 \\
Site supervisor &
\end{tabular}

\subsection{Results and Discussions}

The exploratory factor analysis type adopted was the principal component analysis (PCA) technique which was computed by IBM SPSS Statistics 21 . Since the PCA produces

'components' while factor analysis produces 'factors' [35], thus the term 'components' is used in this study instead of 'factors.' Besides, the term 'items' also represent the influential factors due to the reason that 'items' are used to represent the statements contained in the scale. In the initial step of PCA analysis, the adequacy of the sample and the strength of relationship among items need to be assessed in ensuring the appropriateness of data in this analysis [32]. In this study, the results of the adequacy of the sample by means of Kaiser-Meyer-Olkin (KMO) indicates a value of 0.795 . This value supports the adequacy of the sample as the minimum cut off recommended value by several authors is $0.60[32,35]$. Likewise, the strength relationship threshold value for this study is 0.45 [31]. This indicates that the factor loading value for each item needs to be greater than 0.45 in order to be retained in the scale.

The second step is component extraction which determines the smallest number of component that is best in representing the interrelationship between the set of variables [32]. The components extraction according to the Kaiser's criteria (Eigenvalue $>1$ rule) resulted in 8 components extracted. Lastly, the rotation of component is used to maximise the variance explained among the components $[33,35]$. Although several authors have suggested 'varimax' rotation [35, 37, 38], the appropriate rotation for this study is 'equamax.' The decision on which rotation to use depends on the criteria of having a simple and interpretable structure [31, 32]. Therefore, because 'equamax' rotation demonstrates the most simple and interpretable pattern compared to all other types of rotation after they have been computed, this type of rotation was selected.

After the PCA was computed to 'cluster' inter-related influential factors, the results of components and each item under it were reviewed. Accordingly, regarding with the extraction of components and modification, certain factors were excluded, relocated and combined. As a result, the group name also needed to be altered in order to represent all the influential factors under it. Table 3 indicates the summary of this analysis. 
Table 3: Summary of Suppression of Factor Analysis

\begin{tabular}{|c|c|c|c|c|}
\hline \multicolumn{2}{|c|}{ Before factor analysis } & \multicolumn{3}{|c|}{ After factor analysis } \\
\hline Name of construct & $\begin{array}{l}\text { Number } \\
\text { of items }\end{array}$ & Name of construct & $\begin{array}{l}\text { Number of } \\
\text { items }>0.45\end{array}$ & Remarks \\
\hline • Contractual & 5 & - Contractual & 5 & \\
\hline - Governmental interference & 4 & - Governmental interference & 4 & \\
\hline$\cdot$ Logistics & 10 & - Expediting & 5 & $\square$ The underlying \\
\hline & & - Transportation & 5 & items were split \\
\hline 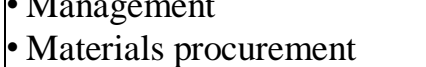 & 15 & - Management & 12 & \\
\hline - Storage & & & & The underlving \\
\hline - Site condition & $\begin{array}{l}4 \\
4\end{array}$ & $\square$ Site storage \& condition & 6 & $\begin{array}{l}\text { items were } \\
\text { merged }\end{array}$ \\
\hline$\square$ Supplier \& manufacturer & 5 & S Supplier & 5 & \\
\hline Total item & 56 & Total item & $\mathbf{5 0}$ & \\
\hline
\end{tabular}

The Table 3 indicates that after the factor analysis, only 50 influential factors remained. This implies that 6 influential factors were dropped as they were less than the threshold value of 0.45 respectively. Apart from that, some of the influential factors were split into two groups, whilst some influential factors were combined after the analysis was conducted. Being that some of the influential factors were modified, hence the group name was also amended as indicated in the table above. The reduction of factors and modification of group verified that only 50 influential factors that categorised into 8 groups are relevant in Malaysian construction industry. Table 4 lists the finalised items of influential factors with their factor loading value that will be adopted for the main survey.

Table 4: Summary of Finalised Influential Factors

\begin{tabular}{|c|l|l|}
\hline Bil & \multicolumn{1}{|c|}{ Construct } & \multicolumn{1}{c|}{ Influential Factor (Factor Loading) } \\
\hline 1 & Contractual (5 items) & $\begin{array}{l}\text { Clear in material specification (.762), Materials meet } \\
\text { specification (.714), No discrepancy between specification \& } \\
\text { drawings (.713), Minimisation in changes of design (.695), } \\
\text { Minimisation in changes of material specification (.632) }\end{array}$ \\
\hline 2 & $\begin{array}{l}\text { Governmental } \\
\text { interference (4 items) }\end{array}$ & $\begin{array}{l}\text { Minimisation in changes of government regulation (.802), No } \\
\text { bureaucratic procedure (.762), On time in custom clearance } \\
\text { for imported materials (.750), Appropriate policy in materials } \\
\text { procurement (.705) }\end{array}$ \\
\hline 3 & Expediting (5 items) & $\begin{array}{l}\text { Efficient use of equipment while handling (.691), Efficient } \\
\text { communication on sites (.594), Easy movement for equipment } \\
(.537), \text { Systematic flow of material (.515), Adequate qualified } \\
\& \text { experience staff (.459) }\end{array}$ \\
\hline 4 & Transportation (5 items) & $\begin{array}{l}\text { Proper material delivery to site (.734), Functional of } \\
\text { equipment (.535), Sufficient protection during unloading } \\
\text { (.527), Proper storing of materials (.520), Materials are not } \\
\text { damaged while handling (.509) }\end{array}$ \\
\hline
\end{tabular}


Table 4: Summary of Finalised Influential Factors (Cont'd)

\begin{tabular}{|c|l|l|}
\hline Bil & \multicolumn{1}{|c|}{ Construct } & \multicolumn{1}{c|}{ Influential Factor (Factor Loading) } \\
\hline 5 & Management (12 items) & $\begin{array}{l}\text { Proper material usage (.698), Adequate IT infrastructure \& } \\
\text { application (.679), Proper material control (.654), Efficient site } \\
\text { management (.609), Proper training on new technologies } \\
\text { (.602), Efficient supervision (.576), Reasonable and } \\
\text { systematic paperwork (.562), Efficient co-ordination (.554), } \\
\text { Systematic inventory documentation (.507), On time } \\
\text { informing material specification (.484), Acceptance of new } \\
\text { technologies (.507), Proper planning (.551) }\end{array}$ \\
\hline 6 & Purchasing (8 items) & $\begin{array}{l}\text { Sufficient of raw materials in market (.725), On time delivery } \\
\text { of materials (.712), Correct delivery as ordered (.693), } \\
\text { Financial capabilities (.540), Acceptable quality of materials } \\
\text { (.478), Correct in ordering (.576), Accurate in taking off } \\
\text { (.483), On time in material procurement (.455) }\end{array}$ \\
\hline 7 & $\begin{array}{l}\text { Site storage \& condition } \\
(6 \text { items) }\end{array}$ & $\begin{array}{l}\text { Enough of material storage (.667), Suitable location of site } \\
\text { storage (.613), Satisfactory of site condition (.597), Accessible } \\
\text { of site access (.559), Efficient function of site layout (.510), } \\
\text { Uncrowded site (.491) }\end{array}$ \\
\hline 8 & Supplier (5 items) & $\begin{array}{l}\text { Materials supplied with pallet (.762), Constant demand of } \\
\text { materials in market (.762), Sufficient of competent suppliers } \\
\text { (.641), Equal materials control among suppliers (.639), } \\
\text { Properly marked materials (.475) }\end{array}$ \\
\hline
\end{tabular}

\subsection{Conclusions}

In conclusion, the results of this analysis indicate that the influential factors have been explored equally in fulfilling the purpose of this factor analysis. The achieved purpose of this analysis with the number of items was reduced, the structure between variables and the construct validity have been examined. The outcome of this analysis is used in the main survey for a research project that aims to develop the effective materials management model.

\section{References}

[1] K. A. Okorocha, "Factors Affecting Effective Materials Management in Building Construction Projects-A Case Study of Selected Building Sites, in Imo State, Nigeria," International Journal of Management Sciences and Business Research, vol. 2(4), pp. 50-59, 2013.

[2] A. Gulghane, and P. Khandve, "Management for Construction Materials and Control of Construction Waste in Construction Industry: A Review," International Journal of Engineering Research and Applications, vol. 5(4), pp. 59-64, 2015.

[3] B. T. Arijeloye, and F.O. Akinradewo, "Assessment of Materials Management on Building Projects in Ondo State, Nigeria," World Scientific News, vol. 55, pp. 168-185, 2016.

[4] S. K. Wan, and M.M. Kumaraswamy, "Industrial Management Approaches for Improving Material Control in Building Services Works," Engineering, Construction and Architectural Management, vol. 16(3), pp. 208-223, 2009.

[5] D. U. Kini, "Materials Management: The Key to Successful Project Management," Journal of Management in Engineering, vol. 15(1), pp. 30-34, 1999.

[6] R. Navon, and O. Berkovich, "An Automated Model for Materials Management and Control," Construction Management and Economics, vol. 24(6), pp. 635-646, 2006.

[7] S. Donyavi, and R. Flanagan. "The Impact of Effective Material Management on Construction Site Performance for Small and Medium Sized Construction Enterprises," in Proceedings of the 25th Annual ARCOM Conference, Nottingham, UK, 2009.

[8] K. A. Okorocha, "Evaluation of Materials Management Strategies in the Nigerian Construction Industry-A Case Study of Selected Buildings Sites in Lagos State," International Journal of Management Sciences and Business Research, vol. 2(3), pp. 82-90, 2013. 
[9] F. Wang, Y. W. Su, and C. F. Li, "Fuzzy AHP Applying in the Material Management of Construction Project," Applied Mechanics and Materials, vol. 275, pp. 2714-2717, 2013.

[10] V. Kulkarni, R. Sharma, and M. Hote, "Factors Affecting Material Management on Construction Site," International Research Journal of Engineering and Technology, vol. 4(1), pp. 474-478, 2017.

[11] M. R. Manavazhi, and D. K. Adhikari, "Material and Equipment Procurement Delays in Highway Projects in Nepal," International Journal of Project Management, vol. 20(8), pp. 627-632, 2002.

[12] M. M. Azambuja, and W. J. O'Brien. "Investigation of Supply Chain Management Practices in Industrial Projects: State of Practice vs. State of Knowledge," in Construction Research Congress 2009: Building a Sustainable Future, 2009.

[13] A. P. Chan, D. Scott, and E.W. Lam, "Framework of Success Criteria for Design and Build Projects," Journal of Management in Engineering, vol. 18(3), pp. 120-128, 2002.

[14] A. H. Memon, "Structural Modelling of Cost Overrun Factors in Construction Industry," Johor, Universiti Tun Hussein Onn Malaysia, 2013.

[15] Z. Ren, C. J. Anumba, and J. Tah, "RFID-facilitated Construction Materials Management (RFIDCMM)-A Case Study of Water-supply Project," Advanced Engineering Informatics, vol. 25(2), pp. 198-207, 2011.

[16] N. Kasim, and P. A. S. Ern, "The Awareness of ICT Implementation for Materials Management in Construction Projects," International Journal of Computer and Communication Technology, vol. 2(1), pp. 1-10, 2010.

[17] J. T. Arnold, S. N. Chapman, and L. M. Clive, "Introduction to Materials Management," 6th ed., New Jersey, Pearson Education Inc, 2008.

[18] W. C. Benton, and L. McHenry, "Construction Purchasing and Supply Chain Management," New York, The McGraw-Hill Companies Inc, 2010.

[19] N. Kasim, "ICT Implementation for Materials Management in Construction Projects: Case Studies," Journal of Construction Engineering and Project Management, vol. 1(1), pp. 31-36, 2011.

[20] C. H. Caldas, C. L. Menches, P. M. Reyes, L. Navarro, and D. M. Vargas, "Materials Management Practices in the Construction Industry," Practice Periodical on Structural Design and Construction, vol. 20(3), pp. 04014039-1-8, 2014.

[21] C. Ayegba, "An Assessment of Material Management on Building Construction Sites," Civil and Environmental Research, vol. 3(5), pp. 18-22, 2013.

[22] A. Kazaz, E. Manisali, and S. Ulubeyli, "Effect of Basic Motivational Factors on Construction Workforce Productivity in Turkey," Journal of Civil Engineering and Management, vol. 14(2), pp. 95106, 2008.

[23] R. A. Rivas, J. D. Borcherding, V. Gonzalez, and L. F. Alarcon, "Analysis of Factors Influencing Productivity Using Craftsmen Questionnaires: Case Study in a Chilean Construction Company," Journal of Construction Engineering and Management, vol. 137(4), pp. 312-320, 2010.

[24] N. Kasim, A. Shamsuddin, R. Zainal, and N. C. Kamarudin, "Implementation of RFID technology for real-time materials tracking process in construction projects," in Humanities, Science and Engineering (CHUSER), IEEE Colloquium, 2012.

[25] M. Safa, A. Shahi, C. T. Haas, and K. W. Hipel, "Supplier Selection Process in an Integrated Construction Materials Management Model," Automation in Construction, vol. 48, pp. 64-73, 2014.

[26] I. Abdul Rahman, and S. Nagapan, "Causative Factors of Construction Waste Generation in Malaysia," Johor, Penerbit UTHM, 2015.

[27] A. Enshassi, M. Sundermeier and M. A. Zeiter, "Factors Contributing to Rework and their Impact on Construction Projects Performance," International Journal of Sustainable Construction Engineering and Technology, vol. 8(1), pp. 12-33, 2017.

[28] S. P. Wanjari and G. Dobariya, "Identifying Factors Causing Cost Overrun of the Construction Projects in India," Sādhanā, vol. 41(6), pp. 679-693, 2016.

[29] M. A. Hertzog, "Considerations in Determining Sample Size for Pilot Studies," Research in Nursing and Health, vol. 31(2), pp. 180-191, 2008.

[30] W. L. Neuman, "Social Research Methods-Qualitative and Quantitative Approaches," 7th ed., Boston, Pearson Education Inc, 2011.

[31] R. F. DeVellis, "Scale Development: Theory and Applications," 3rd ed., California, SAGE Publications Inc, 2012.

[32] J. Pallant, "SPSS Survival Manual," 4th ed., Australia, Allen \& Unwin, 2011.

[33] A. Field, "Discovering Statistics Using SPSS," 3rd ed., London, Sage Publications Ltd, 2009.

[34] B. Williams, A. Osman, and T. Brown, "Exploratory Factor Analysis: A Five-step Guide for Novices," Australasian Journal of Paramedicine, vol. 8(3), pp. 1-13, 2010.

[35] B. G. Tabachnick, and L. S. Fidell, "Using Multivariate Statistics," 6th ed., New Jersey, Pearson Education Inc, 2013. 
[36] G. A. Johanson and G. P. Brooks, " Initial Scale Development: Sample Size for Pilot Studies," Educational and Psychological Measurement, vol 70(3), pp. 394-400, 2010.

[37] M. F. Ahmad, "Basic Statistical Analysis: Step by Step Using SPSS," Johor, Penerbit UTHM, 2016.

[38] O. S. Dosumu and H. N. Onukwube, "Analysis of Project Success Criteria in the Nigerian Construction Industry," International Journal of Sustainable Construction Engineering and Technology, vol. 4(1), pp. 31-47, 2013.

[39] Y. Shan, D. Zhai, P. M. Goodrum, C. T. Haas, C. H. Caldas, "Statistical Analysis of the Effectiveness of Management Programs in Improving Construction Labor Productivity on Large Industrial Projects," Journal of Management in Engineering, vol. 32(1), pp. 04015018-1-10, 2015.

[40] A. R. Patil, and S. V. Pataskar, "Analyzing Material Management Techniques on Construction Project," International Journal of Engineering and Innovative Technology, vol. 3(4), pp. 96-100, 2013.

[41] T. P. Madhavi, S. V. Mathew, and R. Sasidharan, "Material Management in Construction: A Case Study," International Journal of Research in Engineering and Technology, vol. 2(1), pp. 400-403, 2013.

[42] J. M. Sardroud, "Influence of RFID Technology on Automated Management of Construction Materials and Components," Scientia Iranica, vol. 19(3), pp. 381-392, 2012.

[43] K. V. Patel, and C. M. Vyas, "Construction Materials Management on Project Sites," in National Conference on Recent Trends in Engineering \& Technology, 2011.

[44] J. P. Spillane, L. O. Oyedele, J. Von Meding, A. Konanahalli, B. E. Jaiyeoba, and I. K. Tijani, "Challenges of UK/Irish Contractors Regarding Material Management and Logistics in Confined Site Construction," International Journal of Construction Supply Chain Management, vol. 1(1), pp. 25-42, 2011.

[45] J. U. D. Hatmoko, and S. Scott, "Simulating the Impact of Supply Chain Management Practice on the Performance of Medium- sized Building Projects," Construction Management and Economics, vol. 28(1), pp. 35-49, 2010.

[46] C. C. Nwachukwu, and F. I. Emoh, "A Systems Approach in Analysing Material Constraining Factors to Construction Project Management Success in Nigeria," Interdisciplinary Journal of Contemporary Research in Business, vol. 2(5), pp. 90-104, 2010.

[47] A. Fearne, and N. Fowler, "Efficiency Versus Effectiveness in Construction Supply Chains: The Dangers of "Lean" Thinking in Isolation," Supply Chain Management: An International Journal, vol. 11(4), pp. 283-287, 2006.

[48] N. Kasim, C. Anumba, and A. Dainty. "Improving Materials Management Practices on Fast-Track Construction Projects," in 21st Annual ARCOM Conference, SOAS, University of London, 2005.

[49] H. R. Thomas, D. R. Riley, and J. I. Messner, "Fundamental Principles of Site Material Management," Journal of Construction Engineering and Management, vol. 131(7), pp. 808-815, 2005.

[50] L. Mahdjoubi, and J. Yang, "An Intelligent Materials Routing System on Complex Construction Sites," Logistics Information Management, vol. 14(5/6), pp. 337-344, 2001.

[51] C. Formoso, and V. Revelo, "Improving the Materials Supply System in Small-sized Building Firms," Automation in Construction, vol. 8(6), pp. 663-670, 1999.

[52] A. Agapiou, L. E. Clausen, R. Flanagan, G. Norman, and D. Notman, "The Role of Logistics in the Materials Flow Control Process," Construction Management and Economics, vol. 16(2), pp. 131-137, 1998.

[53] H. Abdul Rahman, and M. N. Alidrisyi, "A Perspective of Material Management Practices in a Fast Developing Economy: the Case of Malaysia," Construction Management and Economics, vol. 12(5), pp. 413-422, 1994. 


\section{Appendix A}

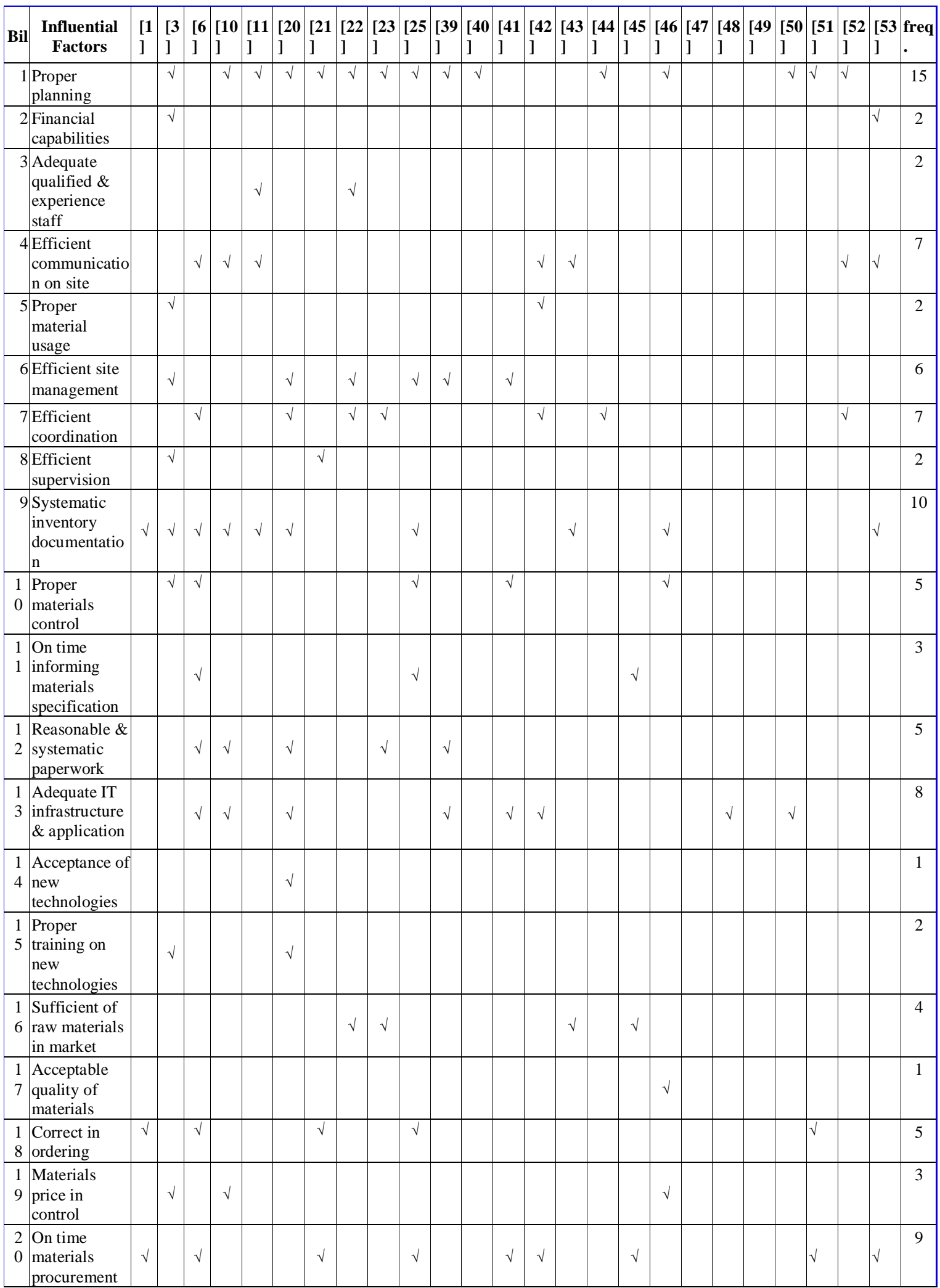




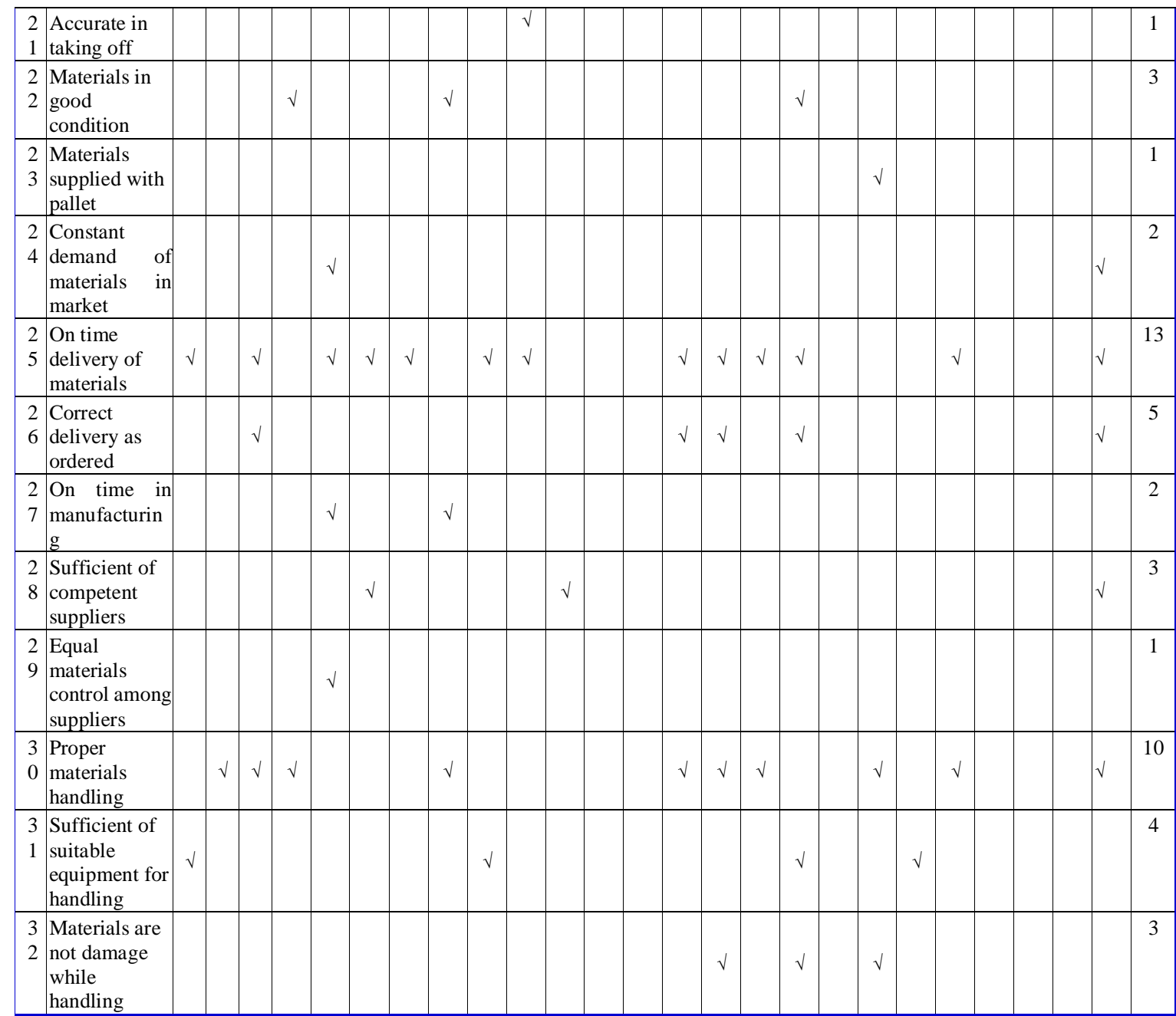

\section{Appendix A (Cont'd)}


International Journal of Sustainable Construction Engineering \& Technology (ISSN: 2180-3242) Vol 9, No 2, 2018

\begin{tabular}{|c|c|c|c|c|c|c|c|c|c|c|c|c|c|c|c|c|c|c|c|c|c|c|c|c|c|c|}
\hline Influe ntial Factors & [1] & [3] & {$[6]$} & {$[10]$} & [11] & [20] & [21] & |22] & [23] & $\mid 25]$ & [39] & [40] & [41] & {$[42]$} & {$[43]$} & {$[44]$} & {$[45]$} & [46] & [47] & [48] & [49] & [50] & [51] & [52] & [53] & freq. \\
\hline 33 Functional of equipment & & & & & & & & & & & & & & & & & & & 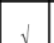 & & & & & & & 1 \\
\hline $\begin{array}{l}34 \mid \text { Proper materials delivery } \\
\text { to site }\end{array}$ & & $\checkmark$ & & $\checkmark$ & & $\checkmark$ & & & & & & & & & & & & & v & & v & & & $\mathrm{v}$ & v & 7 \\
\hline $\begin{array}{l}35 \text { Easy movement for } \\
\text { equipment }\end{array}$ & & & $\sqrt{ }$ & & $\checkmark$ & & & $\checkmark$ & $\checkmark$ & & & & & & & v & & & & & $\checkmark$ & & & & & 6 \\
\hline \begin{tabular}{l|l}
36 & Efficient use of \\
equipment while handling
\end{tabular} & $\checkmark$ & & & & & $\checkmark$ & & & & & & & & & & $\checkmark$ & & & & & & & & v & & 4 \\
\hline $377 \begin{array}{l}\text { Systematic flow of } \\
\text { materials }\end{array}$ & $\checkmark$ & & & & & $\checkmark$ & & $\checkmark$ & & & & $\checkmark$ & & $\checkmark$ & & & & & $\checkmark$ & $\checkmark$ & & $\checkmark$ & v & $\mathrm{v}$ & v & 11 \\
\hline $\begin{array}{l}38 \\
\begin{array}{l}\text { Sufficient protection } \\
\text { during unloading }\end{array}\end{array}$ & & & & & & & & & & & & & & & & & & & $\checkmark$ & & & & & & & 1 \\
\hline \begin{tabular}{l|l}
39 & $\begin{array}{l}\text { Properly marked } \\
\text { materials }\end{array}$
\end{tabular} & & & & & & & & $\checkmark$ & & & & & & $\checkmark$ & & & & & & & $\checkmark$ & & & $\mathrm{v}$ & & 4 \\
\hline 40 Suitable site storage & & & ل & & & & & & & $\sqrt{ }$ & & & ل & & & ل & & & ل & $\sqrt{ }$ & ل & v & & & & 8 \\
\hline $\begin{array}{l}41 \text { Enough of material } \\
\text { storage }\end{array}$ & $\checkmark$ & $\checkmark$ & $\checkmark$ & & & & $\checkmark$ & & & & & & & $\checkmark$ & v & $\checkmark$ & & $\checkmark$ & $\checkmark$ & v & $\checkmark$ & & & & & 11 \\
\hline $\begin{array}{l}42 \text { Proper storing of } \\
\text { materials }\end{array}$ & & & & & & & & & & & & & & $\checkmark$ & & $\checkmark$ & & & & & $\checkmark$ & & & & & 3 \\
\hline \begin{tabular}{l|l|}
43 & $\begin{array}{l}\text { Materials stored near } \\
\text { from working area }\end{array}$
\end{tabular} & & & & & & & & & $\checkmark$ & & & & & & $\checkmark$ & & & & & & & & & & & 2 \\
\hline 44 Accessible of site access & & $\checkmark$ & & & & & & & & & & & & & & $\checkmark$ & & & & & & & & & & 2 \\
\hline 45 Satisfactory site condition & & & & & & & & & & l & & & & & & & & & & & & & & & & 1 \\
\hline $\begin{array}{l}46 \text { Efficient function of site } \\
\text { layout }\end{array}$ & & & & & & & & & & & & & & & & & & & & & $\checkmark$ & $\checkmark$ & & & & 2 \\
\hline \begin{tabular}{l|l|l|}
47 & Uncrowded site \\
\end{tabular} & & & & & & & & $\sqrt{ }$ & & & & & & & & $\sqrt{ }$ & & & & & & & & & v & 3 \\
\hline \begin{tabular}{rl|}
48 & $\begin{array}{l}\text { Minimization in changes } \\
\text { of materials specification }\end{array}$ \\
\end{tabular} & & & & & & & & & & $\checkmark$ & & & & & & & & $\sqrt{ }$ & & & & & & & & 2 \\
\hline \begin{tabular}{l|l}
49 & Minimization in changes \\
of design
\end{tabular} & & & & & & & $\checkmark$ & $\checkmark$ & & & & & & & & & & & & & & & & & & 2 \\
\hline \begin{tabular}{l|l}
50 & $\begin{array}{l}\text { Clear in materials } \\
\text { specification }\end{array}$
\end{tabular} & & & v & & & & & & $\sqrt{ }$ & & & & & & & & & v & & & & & & & & 3 \\
\hline $\begin{array}{l}51 \text { No discrepancy between } \\
\text { specification \& drawings }\end{array}$ & & & & & & & & & & & & & & & v & & & & & & & & $\sqrt{ }$ & & & 2 \\
\hline $\begin{array}{l}52 \mid \begin{array}{l}\text { Materials meet } \\
\text { specification }\end{array} \\
\end{array}$ & & & & & & & & & & & & & & & & & & & & & & & $\sqrt{ }$ & & & 1 \\
\hline \begin{tabular}{l|l|}
53 & $\begin{array}{l}\text { pppropriate policy in } \\
\text { materials procurement }\end{array}$ \\
\end{tabular} & & & & & $\sqrt{ }$ & & & & & & & & & & & & & & & & & & & & & 1 \\
\hline $\begin{array}{l}54 \text { On time in custom } \\
\text { clerance for imported } \\
\text { materials }\end{array}$ & & & & & $\sqrt{ }$ & & & & & & & & & & & & & & & & & & & & & 1 \\
\hline \begin{tabular}{|l|l|}
55 & $\begin{array}{l}\text { Minimization in changes } \\
\text { of government regulation }\end{array}$
\end{tabular} & & & & & & & & & & & & & & & & & & & $\checkmark$ & & & & & & & 1 \\
\hline $\begin{array}{l}56 \\
\begin{array}{l}\text { No bureaucratic } \\
\text { procedure }\end{array}\end{array}$ & & & & & $\sqrt{ }$ & & & & & & & & & & & & & & & & & & & & & 1 \\
\hline Total & 8 & 13 & 16 & 9 & 12 & 13 & 7 & 13 & 9 & 13 & 5 & 2 & 5 & 12 & 10 & 11 & 8 & 8 & 10 & 5 & 9 & 5 & 6 & 7 & 12 & \\
\hline Country investigated & 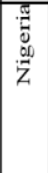 & 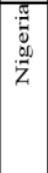 & 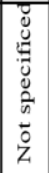 & $\stackrel{\frac{g}{\pi}}{\sharp}$ & 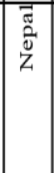 & $\frac{n}{5}$ & 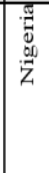 & 商 & Uू & 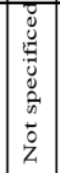 & $n^{n}$ & 覀 & 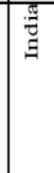 & 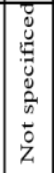 & 吾 & $\frac{1}{5}$ & 光 & 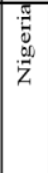 & है & 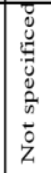 & $\frac{n}{5}$ & है & 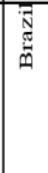 & 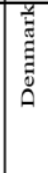 & 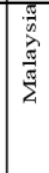 & \\
\hline
\end{tabular}

